in the "Studies and Reports" series of the University of London Institute of Education (London : Oxford University Press. Pp. 110. 3s. 6d.). The lectures, originally delivered in 1935, have been revised and brought up to date and supplemented with memoranda designed to remove, if possible, the imaginary bases for the accusation made by Mr. Gandhi and others that the British Government systematically destroyed an indigenous system of elementary schools and with it a literacy which the schools are presumed to have created. Among the many factors which have militated against the success of Indian educational policies, Sir Philip stresses the extreme lengths to which the policy of devolution was carried with a blind faith that local bodies would learn by making mistakes, the amenability of the Government to pressure exercised by the vocal middle classes in favour of diverting to secondary and higher education funds which ought to have gone to primary education, the extent to which universities have been financially dependent on examination fees and the overerowding of universities with students who ought never to have been admitted. It has been said that the nineteenth century Liberal thought he knew the final truths about education and failed to recognize that it must serve the community as well as the individual. Sir Philip mentions several hopeful indications, including the work of the social service leagues which he helped to establish at Dacea, of the springing up in Indian educational circles of a new spirit of service to the community.

\section{The Carnegie Corporation of New York}

THE report of the president of the Carnegie Corporation of New York, Frederick P. Keppel, for the year ended September 30 records the distribution of grants amounting to nearly four million dollars (including nearly half a million from the Corporation's British Dominions and Colonies Fund) in the follow. ing proportions: endowment and support of universities, colleges and schools 22 , the arts 17 , library interests 15, research studies and publications 14, adult education 5, miscellaneous 27 per cent. It is a document of outstanding interest to trustees and administrators of funds for educational, scientific and cultural purposes and to prospective benefactors and beneficiaries. Highly important questions of principle and policy are lucidly and briefly discussed under the headings "The Public and Foundations", "Funds for Philanthropy" and "Board Procedure". It appears that whilst the volume of large gifts and bequests, derived as they are from fortunes made under conditions which are unlikely to recur, tends to diminish, the funds of the various community trusts made up of relatively small individual contributions have grown steadily in the past ten years from sixteen to fifty million dollars, and the president believes that "current contributions from public funds, from industry and commerce, plus the cumulative contributions of private endowments, are together taking over a steadily increasing share of the total load" of the finance of educational, scientific and cultural enterprises.

\section{Training for Citizenship}

A REview of the Corporation's experience in the field of general education leads to some interesting reflections on the present status and influence of the Graduate School (that "sacred cow in American education, to be worshipped rather than studied, understood, and improved") and the extent to which students destined for the professions are truly educated in the sense of being prepared for life. Their education must, it is contended, "give far more consideration than it does at present to the place of the professionally trained men and women in a modern community, the place that such men and women might take as a united group, not divided and weakened in their influence as at present by an over-emphasis on the spirit and traditions of the separate professional guilds". While education cannot alone create an aristocracy of trained intelligence, it can have regard to such an ideal and foster attitudes that would lead professional men and women to work together rather than separately in contributing to the solution of our political and social problems.

\section{Lines of Magnetic Force}

Prof. C. Coleridge Farr, of Canterbury College, Christchurch, New Zealand, has sent a communication in which he advocates the preparation of accurate charts showing the lines of magnetic force running from the south magnetic pole to the north magnetic pole. Prof. Farr points out that the secular change in declination at any observing station is the parallactic angle subtended by the movement of either pole as viewed along a line of magnetic force, and he considers that the comparison of charts, showing the lines of force at different epochs, would lead to a better understanding of the nature of secular variation. The lines of force could be sketched in on existing declination charts, but there would be obvious difficulties in drawing the lines all the way from pole to pole. In forwarding Prof. Farr's letter, H. F. Skey, director of the Magnetic Observatory, Christchurch, N.Z., directs attention to the smoothed charts of such lines given by A. G. MeNish in Terrestrial Magnetism, 41, 37 (1936). The question is whether unsmoothed charts on a large scale would be sufficiently reliable and sufficiently useful to justify the cost of publication.

\section{National Museum of Wales}

AT a Court of Governors of the National Museum of Wales held at Aberystwyth on May 23, Lord Harlech from the chair reported on the result of his recent visit to the United States of America, when he was accompanied by Sir Cyril Fox, the director, to appeal to Welshmen in the States on behalf of the National Museum. The sum of $£ 10,000$ has already been received in response to the appeal. Lord Harlech stated that the attitude of Welsh Americans towards the Museum was such that the response would have been much greater had it not been for the international tension in Europe at the present time. The variety and range of the recent accessions to the collections of the Museum, 
which were reported to the governors by Sir Cyril Fox on this occasion, are an indication of the activities of the Museum in the preservation and display of objects illustrating the history and culture of the Welsh people. Among these were a collection of neolithic finds from Breconshire, a thirteenth-fifteenth century stone fireplace from the Vale of Glamorgan, and a turned chair of mid-sixteenth century date; while among objects deposited were an important collection of carved stones dated at about A.D. 1230-40 from Castell-y-Bere, and the extremely interesting iron age fire-dog found in 1852 at Carreg Coedog Farm, Denbighshire. It was also reported that the services of the Museum had been called upon by the Office of Works to report on the antiquities of Pembrokeshire, which are threatened by a tank school.

\section{Inland Water Survey Report}

The third annual report of the Inland Water Survey Committee, issued by the Ministry of Health and the Scottish Office (H.M. Stationery Office, $4 d$. net), while recording a year of useful activity in various directions, chiefly with the aid of external agencies, finds occasion to express disappointment at the results achieved and to state the conviction of the Committee that action should be taken by the Government, financially or otherwise, for ensuring the extension of the work in both England and Wales and Scotland. The Committee points out that it has no staff at its disposal for taking actual measurements, and that it has to rely in England and Wales (and to some extent in Scotland) on voluntary action by catchment boards and others for the execution of this part of the work of the Survey. It finds, moreover, that relatively very few suitable records of river flow are being kept, and that neither the information available from water undertakers, nor that from catchment boards, is sufficient in scope or adequate in quality to enable a comprehensive survey to be made. It is convinced that in order to be of real use, such a survey should be carried out on similar lines to the Ordnance Survey or the Geological Survey in their respective fields. It may be pointed out that this was precisely the view taken by the British Association Committee four years ago, when the Government reluctantly agreed at its instance to institute a survey.

As regards the actual progress made with the Survey, the examination of river basins, begun in the first and second reports, has been continued, and the results of the investigation of the river basins of the Earn (Perthshire), Eden (Fife), Tyne (East Lothian), Trent, Great Ouse, Wye and Nith (Dumfries. shire) are described in the report. During the year, the Department of Agriculture for Scotland was authorized to spend $£ 500$ on the equipment and maintenance of river discharge measurement stations. The existing level-indicating and recording stations on the Clyde, Kelvin, Irvine and Tay have been maintained and stations established on the Earn, Eden, Tyne and Nith. The Tweed basin has also been reconnoitered. In the sphere of underground water, the field work earried out by the Geological
Survey in the Nene basin has been continued, and work is proceeding on a memoir dealing with the underground water resources of an area which includes Northampton and Oxford. The results of measurements for twenty-eight gauging stations in fourteen river basins, collected by various authorities, have been published as "The Surface Water Year Book of Great Britain, 1935/6". The report also deals with several technical difficulties which have been met with during the process of collecting these statistics, and recommendations are made about recording charts and arrangements for securing accuracy of measurement.

\section{Scientific and Industrial Research in New Zealand}

As admirable survey of the work carried out under the Council of Scientific and Industrial Research, New Zealand, during 1927-38 has been issued by the Department as Bulletin No. 69. It includes accounts of work carried out by the Dairy Research Institute, the Plant Research Bureau and the Wheat Research Institute, as well as of the activities of the Department in soil survey, fruit research, animal research, tobacco research and the work of the research associations. The work of the Dairy Research Institute on the cause and control of openness in cheese is described in some detail, as well as further work on discoloration in cheese, and on cheese manufacture. Reference is made to the work of the Plant Diseases Division on chemical sprays and the spray certification system which has been introduced, as well as on virus diseases of tobacco, tomato and of potato, and the importance of the methods introduced for the control of smut of barley. The contribution of the Wheat Research Institute to the improvement of the technique of wheat growing and harvesting, the growing of varieties most suitable for special districts, and cheapening the cost of production is emphasized, as well as the selection and distribution of a new wheat, Cross 7, which yields as well as standard varieties, and has by itself a baking quality equal to that of the old varieties plus the proportion of Canadian wheat formerly used. Fruit research has covered manurial experiments on fruit tree nutrition, boron as a cure for internal cork of apples, orchard sprays, wrappers for fruit; and the soil survey studies have included reference to the physiological diseases of plants. An important discovery in the field of animal research relates to the wasting diseases caused by deficiencies in the diet of cobalt, to which the bush sickness in the North Island, Morton mains disease in the South Island, and Glenhope ailment in Nelson are due.

\section{Commercial Applications of Blended Light}

In practical work, the term 'blended light' is used to describe the mixture of the light from the ordinary tungsten gas-filled lamps with that from mercury discharge lamps. A. H. Olsen contributes a paper to the Electrical Review for May 26 in which he discusses the blending of the light from these lamps. A gasfilled lamp depends on the light emitted by a tungsten 